\title{
Correlation Studies and Yield Forecasting Regression Model of kharif sorghum [Sorghum bicolor (L.)]
}

\author{
D. D. Burade, M. B. Jadhav* and A. D. Nirwal \\ Department of Agril. Meteorology, VNMKV, Parbhani (M.S.), India \\ *Corresponding author
}

\section{A B S T R A C T}

\section{Keywords}

Kharif sorghum, Growth stages, Correlation, Regression statistical model

Article Info

Accepted: 22 October 2020 Available Online: 10 November 2020
The field experiment was carried out in kharif season 2012-13 for studying relationship between weather parameters and growth of sorghum and to develop the regression model. The sowing date $24^{\text {th }} \mathrm{MW}$ showed significantly superior over the rest of treatments with production of highest grain yield $\left(1482.10 \mathrm{~kg} \mathrm{ha}^{-1}\right)$ followed by sowing in second sowing date $25^{\text {th }} \mathrm{MW}\left(1444.2 \mathrm{~kg} \mathrm{ha}^{-1}\right)$ and lowest grain yield was observed in fourth sowing date $27^{\text {th }}$ MW (1119.31 kg ha $\left.{ }^{-1}\right)$. Correlation between weather parameters and growth stages of sorghum with grain yield showed that all the weather parameters mostly positively and highly significant correlation at different growth stages except flag leaf to boot stage. While, it was found highly and negatively significant correlated at all the growth stages expect panicle initiation to flag leaf; boost stage to heading and dough stage with different weather parameters. The multiple regression coefficients $\left(\mathrm{R}^{2}\right)$ at each stage showed a high degree of goodness of fit as indicated by as high as 0.74 to 0.88 . The regression model for different growth stages was developed and it was found significant. It showed accurate and useful yield prediction because of its error percentage is very less ranging between 0.07 to 4.62 percentages.

\section{Introduction}

Sorghum (Sorghum bicolor (L.) Moench) is an important food crop in India and it is cultivated in tropical and subtropical climates, especially in the semi-arid tropics. It is the fifth most important cereal crop followed by rice, wheat, maize and barley in the world. In India, sorghum is extensively produced and both hybrid and improved varieties of sorghum are taken on large scale. In Maharashtra state, during kharif season jowar is cultivated on 8.82 Mha with production $1.342 \mathrm{Mt}$ and productivity of $1498 \mathrm{~kg} /$ hectare. Rabi Sorghum plays an important role in dry land economy In Maharashtra. The area under rabi sorghum during 2011-12 was 2.38 lakhs hectare with production $1.35 \mathrm{Mt}$ and productivity $567 \mathrm{~kg} /$ hectare (Anonymous 2012). Dryland farming is the backbone of Indian agriculture, as large areas of cultivated land are rainfed. The success or failure of dryland rainfed crops depends mostly on the pattern of monsoon rains. The distribution of 
rainfall in monsoon decides the yield of rainfed crops. To mitigate these losses of kharif sorghum, a field experiment was conducted to find out the suitable sowing date for sustainable yield of rainfed kharif sorghum under erratic behavior of monsoon.

\section{Materials and Methods}

Field experiment was conducted on yield forecasting regression model of Sorghum bicolor (L.) during kharif season 2012-13 at Department of Agricultural Meteorology, Vasantrao Naik Marathwada Krishi Vidyapeeth, Parbhani. The experiment was conducted in split plot design with three replications and four sowing dates as main treatment viz., $\mathrm{D}_{1}\left(24^{\text {th }} \mathrm{MW}\right), \mathrm{D}_{2}\left(25^{\text {th }} \mathrm{MW}\right)$, $\mathrm{D}_{3}\left(26^{\text {th }} \mathrm{MW}\right)$ and $\mathrm{D}_{4}\left(27^{\text {th }} \mathrm{MW}\right)$ and four different varieties as sub treatment viz., $\mathrm{V}_{1}$ (PSH-71), $\mathrm{V}_{2}$ (MSH-51), $\mathrm{V}_{3}$ (BGL-296) and $\mathrm{V}_{4}$ (PVK-801) were sown with spacing $45 \times 15$ $\mathrm{cm}$. The gross plot size was $3.60 \times 2.25$ $\mathrm{m}^{2}$ and net plot size was $2.25 \mathrm{x} 1.8 \mathrm{~m}^{2}$. The sowing of seed was done by dibbling method on respective date of sowing. Recommended packages of practices like thinning, weeding, application of recommended dose of fertilizer i.e. NPK (80:40:40 kgha ${ }^{-1}$ respectively) and pesticide were uniformly applied to each treatment.

Observations on plant were recorded on five plants randomly selected in each replication of all treatments. The data recorded were statistically analyzed by using computerized programme based on technique of analysis of variance and significance for every phenophase of sorghum crop. Regression equation was developed on the basis of crop data (phonological stage wise data) and weather data. The multiple regression was worked out at different growth stages of sorghum i.e. emergence to panicle initiation $\left(\mathrm{P}_{2}\right)$, flag leaf to boot stage $\left(\mathrm{P}_{4}\right)$, heading to 50 $\%$ flowering $\left(\mathrm{P}_{6}\right)$, flowering to milk stage
$\left(\mathrm{P}_{7}\right)$, dough stage $\left(\mathrm{P}_{8}\right)$ and physiological maturity $\left(\mathrm{P}_{9}\right)$ stage. While, for forecasting the yield, most commonly used model are based on following type i.e. multiple regression model and it is given as below.

$$
Y=\beta_{0}+\beta_{1} X_{1}+\beta_{2} X_{2}+\beta_{3} X_{3}+\ldots \ldots \beta_{i} X_{i}
$$

Where,

$\mathrm{Y}$ is yield (Dependent parameter), $\mathrm{Xi}$ is weather parameters (independent parameters) and $\beta_{0}$ and $\beta_{i}$, are constants.

\section{Results and Discussion}

\section{Weather condition during crop growth period}

Total rainfall during crop growth period $\left(24^{\text {th }}\right.$ MW to $45^{\text {th }} \mathrm{MW}$ ) received was $673.9 \mathrm{~mm}$ in 41 rainy days. The maximum and minimum temperature during crop growing period was ranged in between 30.0 to $38.4{ }^{\circ} \mathrm{C}$ and 15.6 to $26.3{ }^{0} \mathrm{C}$ respectively. The morning relative humidity (RH-I) ranged in between from 61 to 95 percent and afternoon relative humidity (RH-II) 26 to 72 percent during crop growing season.

It is observed that average evaporation 5.24 $\mathrm{mm}$ day $^{-1}$ during the crop grooving period; lowest and highest evaporation was recorded $2.8 \mathrm{~mm}\left(36^{\text {th }} \mathrm{MW}\right)$ and $11.2 \mathrm{~mm}$ in $\left(24^{\text {th }}\right.$ $\mathrm{MW}$ ), respectively. The mean BSS during crop growing period (from $24^{\text {th }}$ to $45^{\text {th }} \mathrm{MW}$ ) was recorded $6.39 \mathrm{hrs} \mathrm{day}^{-1}$. The highest value of bright sunshine hours was recorded in $42 \mathrm{MW}$ (10.1 $\mathrm{hrs} \mathrm{day}^{-1}$ ) and lowest BSS in $25 \mathrm{MW}$ (2.7 hrs day $\left.{ }^{-1}\right)$. Highest wind velocity $\left(7.9 \mathrm{~km} \mathrm{hr}^{-1}\right)$ was recorded in $24^{\text {th }} \mathrm{MW}$ and lowest wind velocity $\left(2.0 \mathrm{~km} \mathrm{hr}^{-1}\right)$ was recorded in $41 \mathrm{MW}$. While, it was recorded average $4.95 \mathrm{~km} \mathrm{hr}^{-1}$ during the whole crop growing period. 


\section{Yield attributes}

\section{Test weight (gm)}

The data given in table 1 for test weight (gm per 1000 seeds) is revealed that the mean test weight of kharif sorghum varieties was recorded $30.43 \mathrm{gm}$ and the second sowing (i.e. $25 \mathrm{MW}$ sowing) showed significantly highest mean thousand seed weight (31.66 $\mathrm{gm})$ over the other of sowing dates and it was at par with sowing in $24 \mathrm{MW}$ (30.60 gm) and $27 \mathrm{MW}$ (31.28 gm) sowing date. The similar results were reported by Sonwar et al., (2008) and he stated that the early sowing of kharif sweet sorghum gives highest test weight. It may be due to obtaining most congenial weather condition at each phenophase.

The effect amongst four varieties in thousand seed weight was found significant and the PSH-71 variety observed significantly superior over all the varieties (31.83 gm) in mean thousand seed weight. While, it was at par with variety BGL-296 (31.08 gm). It may be due to varietal characters i.e. yield response to weather parameters. The interaction effect between date of sowing and different cultivars was found to be nonsignificant.

\section{Grain yield ( $\left.\mathrm{kg} \mathrm{ha}^{-1}\right)$}

The mean grain yield per hectare of kharif sorghum (Table 1) was recorded $1335.9 \mathrm{~kg}$ $\mathrm{ha}^{-1}$ and significantly highest grain yield $\left(1482.10 \mathrm{~kg} \mathrm{ha}^{-1}\right)$ was recorded in $24^{\text {th }} \mathrm{MW}$ sowing and it was at par with $25^{\text {th }} \mathrm{MW}$ sowing $\left(1442.2 \mathrm{~kg} \mathrm{ha}^{-1}\right)$. While, lowest grain yield $\left(1119.31 \mathrm{~kg} \mathrm{ha}^{-1}\right)$ was recorded in $27^{\text {th }}$ MW. Similar results were reported by Umrani et al., (1988), Baig and Shankiti (1994), Bhoite and Nimbalkar (1997), Sunil Kausik et al., (2007), Jadhav et al., (2010).

Amongst the four varieties highest grain yield per ha ${ }^{-1}$ was observed in variety PSG-71
(1451.31 kg ha ${ }^{-1}$ ) and lowest in PVK-801 (Parbhani sweta) (1230.2 kg ha ${ }^{-1}$ ). The variety PSH-71 was recorded significantly superior yield over all the remaining varieties. The interaction effect between date of sowing and different varieties was found to be nonsignificant for grain yield.

\section{Fodder yield}

It is understood from the table 1 , that the mean fodder yield was recorded $6908.9 \mathrm{~kg} \mathrm{ha}^{-}$ 1. Second sowing date $25^{\text {th }} \mathrm{MW}$ recorded significantly highest fodder yield $(7310.5 \mathrm{~kg}$ $\mathrm{ha}^{-1}$ ) and lowest in $27^{\text {th }} \mathrm{MW}\left(6541.1 \mathrm{~kg} \mathrm{ha}^{-1}\right)$. Similar results were reported by Alma et al., (1995).

The significant differences in fodder yield amongst the varieties was observed and highest and lowest fodder yield was recorded in variety PSH-71 $\left(7228.2 \mathrm{~kg} \mathrm{ha}^{-1}\right)$ and variety MSH-51 (6484.7 $\left.\mathrm{kg} \quad \mathrm{ha}^{-1}\right)$, respectively. The significantly highest fodder yield was recorded in PSH-71 (7288.2 $\mathrm{kg} \mathrm{ha}^{-1}$ ) over all the rest treatments and it was at par with MSH-51 (7069.9 $\left.\mathrm{kg} \mathrm{ha}^{-1}\right)$.

\section{Biological yield}

The data given in table 1 interprets that the sowing in $24^{\text {th }}$ MW significantly highest biological yield was recorded in $24^{\text {th }} \mathrm{MW}$ $\left(8743.4 \mathrm{~kg} \mathrm{ha}^{-1}\right)$; While, it was at par with sowing in $25^{\text {th }} \mathrm{MW}\left(8741.8 \mathrm{~kg} \mathrm{ha}^{-1}\right)$ while, it was observed lowest $\left(7660.41 \mathrm{~kg} \mathrm{ha}^{-1}\right)$ in 27 MW with mean biological yield $(8244.21 \mathrm{~kg}$ $\left.\mathrm{ha}^{-1}\right)$. Similar results were reported by Suchit K. Rai et al., (2006).

Amongst the four varieties highest biological yield was observed in variety PSH-71 (8679.51 $\mathrm{kg} \mathrm{ha}^{-1}$ ) and lowest biological yield was recorded in MSH-51 (7794.2 kg ha-1). While, it was at par with variety Bhagyalaxi$296\left(8422.6 \mathrm{~kg} \mathrm{ha}^{-1}\right)$. 
Correlation between weather parameters and different growth stages with grain yield

The data of weather parameters for correlation was taken (viz., rainfall, rainy day, temperature, relative humidity, bright sunshine hours, wind speed and evaporation etc.) commutatively and averagely during sorghum crop growing season for all sowing dates and at each phenophase and correlated with yield (Table 2). Weather parameters found significantly correlated with sorghum grain yield at different growth stages. However, highly and positively significant correlation was found at sowing to emergence with wind velocity $(\mathrm{r}=0.732 * *)$; at emergence to panicle initiation with evaporation $(\mathrm{r}=0.640 * *)$ and bright sunshine hours $(\mathrm{r}=0.714 * *)$; at panicle initiation to flag leaf stage with wind velocity $(\mathrm{r}=$ $0.664 * *)$; boot stage to heading with maximum temperature $(\mathrm{r}=0.629 * *)$ at heading to $50 \%$ flowering with minimum temperature ( $\left.\mathrm{r}=0.633^{* *}\right)$; at flowering to milk stage with rain fall $\left(\mathrm{r}=0.850^{* *}\right)$, rainy days $(\mathrm{r}$ $\left.=0.751^{* *}\right)$ and relative humidity-I $(\mathrm{r}=$ $0.721 * *)$; at dough stage with wind velocity ( $\mathrm{r}$ $\left.=0.726^{* *}\right)$ and at Physiological maturity with rainfall $(\mathrm{r}=0.831 * *)$, rainy days $(\mathrm{r}=0.823 * *)$, maximum temperature $(\mathrm{r}=0.801 * *)$ and minimum temperature $\left(\mathrm{r}=0.830^{* *}\right)$. However, it was found negatively and highly significant relation at sowing to emergence with of RH-I ( $\mathrm{r}=-0.747 * *)$ and RH-II ( $\mathrm{r}=$ $\left.0.715^{* *}\right)$; at emergence to panicle initiation with rainy days $\left(\mathrm{r}=-0.656^{* *}\right)$; with $\mathrm{BSS}(\mathrm{r}=-$ $\left.0.688^{* *}, \mathrm{r}=-0.713 * *,-0.802 * *\right)$ at Flag leaf to Boot stage, Heading to $50 \%$ flowering and Flowering to milk stage, respectively and with maximum temperature $(\mathrm{r}=-0.722 * *)$, Evaporation $(\mathrm{r}=-0.668 * *)$ and $\mathrm{BSS}(\mathrm{r}=-$ 0.749) at Physiological maturity.

As per discussed above, highly and positively or negatively influencing weather parameters on crop growth, development and yield of sorghum was observed (Table-2). However, some weather parameters at different growth stages showed positive as well as negative significant effect on growth and yield of sorghum.

It is clearly understood from the table -2 that during initial crop growth stages (sowing to heading) less significant weather parameters was observed minimum temperature and later growth stages (heading to dough stages) afternoon relative humidity and evaporation.

It means that more or less impact of all weather parameters observed directly on yield of sorghum crop with maximum impact of rainfall, rainy days, maximum temperature and bright sunshine hours (BSS).

\section{Correlation between weather parameters and different growth stages with fodder yield}

The data of weather parameters for correlation was taken (viz., rainfall, rainy day, temperature, relative humidity, bright sunshine hours, wind speed and evaporation etc.) commutatively and averagely during sorghum crop growing season for all sowing dates and at each phenophase and correlated with fodder yield (Table 3). Weather parameters found significantly correlated with sorghum fodder yield at different growth stages. However, highly and positively significant correlation was found at sowing to emergence with evaporation $\left(0.705^{* *}\right)$; at emergence to panicle initiation positively significant correlation with evaporation ( $\mathrm{r}$ $\left.=0.555^{*}\right)$ and bright sunshine hours ( $\mathrm{r}=$ $0.652 * *)$; at panicle initiation to flag leaf stage positively significant correlation with rainfall and rainy days $\left(\mathrm{r}=0.711^{*}\right)$ wind velocity $\left(\mathrm{r}=0.689^{* *}\right)$; at flag leaf to boot stage positively significant correlation with afternoon relative humidity $\left(\mathrm{r}=0.715^{* *}\right)$; at 
boot stage to heading with wind speed ( $\mathrm{r}$ $=0.713 * *)$; at Heading to $50 \%$ flowering stage positively significant correlation with minimum temperature $\left(\mathrm{r}=0.705^{* *}\right)$ maximum temperature $\left(\mathrm{r}=0.548^{*}\right)$; flowering to milk stage with rain fall $(\mathrm{r}=0.682 * *)$, rainy days $(\mathrm{r}$ $\left.=0.696^{* *}\right)$ and relative humidity-I $(\mathrm{r}=$ $\left.0.641^{* *}\right)$ relative humidity-II $\left(\mathrm{r}=0.686^{* *}\right)$; at dough stage positively significant correlation with minimum temperature $\left(\mathrm{r}=0.624^{* *}\right)$ and with wind velocity $\left(\mathrm{r}=0682^{* *}\right)$ and at Physiological maturity with rainy days $(\mathrm{r}=$ $\left.0.578^{*}\right)$, minimum temperature $\left(\mathrm{r}=0.518^{*}\right)$, relative humidity-I $\left(\mathrm{r}=0.507^{*}\right)$ and relative humidity-II $(\mathrm{r}=0.520 * *)$; significant relation at sowing to emergence with of RH-I ( $\left.\mathrm{r}=-0.589^{*}\right)$; at emergence to panicle initiation with rainy days $(\mathrm{r}=$ $\left.0.656^{* *}\right)$; with rainfall $\left(\mathrm{r}=-0.642^{* *}, \mathrm{r}=-\right.$ $0.660 * *$,$) Rainy days ( \mathrm{r}=-0.654 * *), \mathrm{r}=-$ $0.627 * *)$ R.H. - I ( $\mathrm{r}=-0.692 * *, \mathrm{r}=-0.649 * *)$ at Flag leaf to Boot stage, at Boot stage to heading respectively. And also Tmax ( $\mathrm{r}=-$ $\left.0.688^{* *}\right)$ R.H.-II ( $\left.\mathrm{r}=-0.681 * *\right)$; at Heading to $50 \%$ flowering minimum temperature $(\mathrm{r}=$ $\left.0.705^{* *}\right)$ and BSS $(\mathrm{r}=-0.693 * *)$; at Flowering to milk stage maximum temperature $(\mathrm{r}=$ $0.642 * *)$ evaporation $\left(\mathrm{r}=--0.658^{* *}\right)$ and $\mathrm{BSS}\left(\mathrm{r}=-0.703^{* *}\right)$; at Dough stage maximum temperature $(\mathrm{r}=-0.714 * *)$

However, it was found negatively and highly

Table.1 Mean test weight (gm 1000 grain $\left.^{-1}\right)$, grain yield $\left(\mathrm{kg} \mathrm{ha}^{-1}\right)$, fodder yield $\left(\mathrm{kg} \mathrm{ha}^{-1}\right)$ and biological yield $\left(\mathrm{kg} \mathrm{ha}^{-1}\right)$

\begin{tabular}{|c|c|c|c|c|}
\hline Treatments & $\begin{array}{l}\text { Test weight } \\
\text { (gm) }\end{array}$ & $\begin{array}{l}\text { Grain yield } \\
\left(\mathrm{kg} \mathrm{ha}^{-1}\right)\end{array}$ & $\begin{array}{l}\text { Fodder yield } \\
\quad\left(\mathrm{kg} \mathrm{ha}^{-1}\right)\end{array}$ & $\begin{array}{l}\text { Biological yield } \\
\quad\left(\mathrm{kg} \mathrm{ha}^{-1}\right)\end{array}$ \\
\hline \multicolumn{5}{|c|}{ Date of Sowing } \\
\hline $24 \mathrm{MW}$ & 30.60 & 1482.10 & 7261.3 & 8743.4 \\
\hline $25 \mathrm{MW}$ & 31.66 & 1431.30 & 7310.5 & 8741.8 \\
\hline $26 \mathrm{MW}$ & 31.28 & 1311.00 & 6522.6 & 7833.6 \\
\hline $27 \mathrm{MW}$ & 28.19 & 1119.31 & 6541.1 & 7660.41 \\
\hline $\mathrm{SE} \pm$ & 0.76 & 26.62 & 174.46 & 178.62 \\
\hline CD at $5 \%$ & 2.24 & 77.59 & 508.46 & 520.56 \\
\hline \multicolumn{5}{|l|}{ Varieties } \\
\hline PSH-71 & 31.83 & 1451.31 & 7228.2 & 8679.51 \\
\hline MSH-51 & 29.25 & 1309.50 & 6484.7 & 7794.2 \\
\hline BGL-296 & 31.08 & 1352.7 & 7069.9 & 8422.6 \\
\hline PVK-801 & 29.58 & 1230.2 & 6847.7 & 8077.9 \\
\hline $\mathrm{SE} \pm$ & 0.50 & 23.23 & 179.77 & 183.96 \\
\hline CD at $5 \%$ & 1.47 & 67.71 & 523.92 & 536.13 \\
\hline \multicolumn{5}{|c|}{ D $x$ V Interaction } \\
\hline $\mathrm{SE} \pm$ & 1.01 & 46.47 & 359.54 & 367.91 \\
\hline CD at $5 \%$ & NS & NS & NS & NS \\
\hline G.M & 30.43 & 1335.9 & 6908.9 & 8244.21 \\
\hline
\end{tabular}


Table.2 Correlations between weather parameter and different growth stages of sorghum with grain yield

\begin{tabular}{|c|c|c|c|c|c|c|c|c|c|}
\hline \multirow{2}{*}{$\begin{array}{c}\text { Weather } \\
\text { parameters }\end{array}$} & \multicolumn{9}{|c|}{ Phenophase stages in Sorghum } \\
\hline & $\mathbf{P}_{1}$ & $\mathbf{P}_{2}$ & $\mathbf{P}_{3}$ & $\mathbf{P}_{4}$ & $\mathbf{P}_{5}$ & $\mathbf{P}_{6}$ & $\mathbf{P}_{7}$ & $\mathbf{P}_{8}$ & $\mathbf{P}_{9}$ \\
\hline Rainfall (mm) & 0.113 & -0.456 & $0.531 *$ & $0.507 *$ & 0.105 & $-0.603 *$ & $0.850 * *$ & $0.484 *$ & $0.831 * *$ \\
\hline Rainy days & -0.247 & $-0.656 * *$ & $0.562 *$ & $-0.528 *$ & $0.540 *$ & -0.385 & $0.751 * *$ & $0.512 *$ & $0.823 * *$ \\
\hline $\operatorname{Tmax}\left({ }^{\circ} \mathbf{C}\right)$ & $0.543^{*}$ & $0.581 *$ & 0.107 & 0.035 & $0.629 * *$ & 0.335 & $-0.539 *$ & -0.372 & $-0.772 * *$ \\
\hline $\operatorname{Tmin}\left({ }^{\circ} \mathbf{C}\right)$ & 0.322 & 0.005 & $0.592 *$ & -0.286 & $-0.532 *$ & $0.633 * *$ & 0.234 & $0.615^{*}$ & $0.801 * *$ \\
\hline RH - I (\%) & $-0.747 * *$ & $-0.603 *$ & $\begin{array}{c}0.657 * \\
*\end{array}$ & $-0.590 *$ & $-0.595^{*}$ & -0.152 & $0.598^{*}$ & $0.591^{*}$ & $0.830 * *$ \\
\hline RH - II (\%) & $-0.715 * *$ & $-0.524 *$ & 0.205 & $0.539 *$ & 0.194 & -0.222 & $0.721 * *$ & 0.440 & $0.617 *$ \\
\hline $\operatorname{Evp}(\mathbf{m m})$ & $0.743 * *$ & $0.640 * *$ & $0.476^{*}$ & $-0.610 *$ & -0.275 & 0.040 & -0.462 & -0.211 & $-0.668 * *$ \\
\hline B.S.S (hrs) & 0.236 & $0.714 * *$ & $\stackrel{-}{0.601 *}$ & $-0.688 * *$ & 0.288 & $-0.713 * *$ & $-0.802 * *$ & -0.469 & $-0.749 * *$ \\
\hline W.V $\left(\mathrm{Kmhr}^{-1}\right)$ & $0.732 * *$ & $-0.621 *$ & $\begin{array}{c}0.664 * \\
*\end{array}$ & $0.517^{*}$ & 0.131 & -0.329 & $0.590^{*}$ & $0.726 * *$ & 0.400 \\
\hline
\end{tabular}

(* Significant at $0.05 \%, * *$ Significant at $0.01 \%$ )

$\mathbf{P}_{\mathbf{1}^{-}}$Sowing to emergence $\quad \mathbf{P}_{\mathbf{2}}$ - Emergence to panicle initiation (PI)

$\mathbf{P}_{4^{-}}$- Flag leaf to boot stage

$\mathbf{P}_{7}$ - Flowering to milk stage
$\mathbf{P}_{5}$ - Boot stage to heading

$\mathbf{P}_{\mathbf{8}^{-}}$- Dough stage
$\mathbf{P}_{\mathbf{3}}$ - PI to flag leaf stage

$\mathbf{P}_{\mathbf{6}}-$ Heading to $50 \%$ flowering

$\mathbf{P}_{\text {9- }}$ Physiological maturity

Table.3 Correlations between weather parameter and different growth stages of sorghum with fodder yield

\begin{tabular}{|c|c|c|c|c|c|c|c|c|c|}
\hline \multirow{2}{*}{$\begin{array}{c}\text { Weather } \\
\text { parameters }\end{array}$} & \multicolumn{9}{|c|}{ Phenophase stages in Sorghum } \\
\hline & $\mathbf{P}_{1}$ & $\mathbf{P}_{2}$ & $\mathbf{P}_{3}$ & $\mathbf{P}_{4}$ & $\mathbf{P}_{5}$ & $\mathbf{P}_{6}$ & $\mathbf{P}_{7}$ & $\mathbf{P}_{8}$ & $\mathbf{P}_{9}$ \\
\hline Rainfall (mm) & 0.036 & -0.289 & $0.711^{* *}$ & $-0.642 * *$ & $-0.660 * *$ & -0.391 & $0.682 * *$ & 0.336 & 0.481 \\
\hline Rainy days & -0.238 & -0.462 & $0.711 * *$ & $-0.654 * *$ & $-0.627 * *$ & -0.404 & $0.696 * *$ & 0.333 & $0.578^{*}$ \\
\hline $\operatorname{Tmax}\left({ }^{\circ} \mathbf{C}\right)$ & $0.588^{*}$ & 0.427 & 0.040 & -0.055 & $-0.688 * *$ & $0.548^{*}$ & $-0.642 * *$ & $-0.714 * *$ & $-0.532 *$ \\
\hline $\operatorname{Tmin}\left({ }^{\circ} \mathbf{C}\right)$ & $0.668^{* *}$ & -0.169 & 0.3970 & $-0.663 * *$ & -0.460 & $\begin{array}{c}0.705^{*} \\
*\end{array}$ & 0.486 & $0.624 * *$ & $0.518^{*}$ \\
\hline RH - I (\%) & $-0.589 *$ & $-0.520 *$ & 0.203 & $-0.692 * *$ & $-0.649 * *$ & $-0.521 *$ & $0.641 * *$ & 0.197 & $0.507^{*}$ \\
\hline RH - II (\%) & -0.405 & -0.494 & 0.219 & $0.715^{* *}$ & $-0.681 * *$ & $-0.567 *$ & $0.686^{* *}$ & 0.273 & $0.520 *$ \\
\hline $\operatorname{Evp}(\mathbf{m m})$ & $0.705^{* *}$ & $0.555^{*}$ & 0.301 & $-0.623 * *$ & $0.712 * *$ & 0.436 & $-0.658 * *$ & $-0.506^{*}$ & -0.344 \\
\hline B.S.S (hrs) & 0.223 & $0.652 * *$ & -0.412 & $-0.547 *$ & $-0.620^{*}$ & $\begin{array}{c}- \\
0.693 * \\
*\end{array}$ & $-0.703 * *$ & $-0.609 *$ & -0.395 \\
\hline W.V $\left(\mathrm{Kmhr}^{-1}\right)$ & $0.600^{*}$ & -0.284 & $0.689 * *$ & $0.511^{*}$ & $0.713 * *$ & -0.418 & 0.088 & $0.682 * *$ & $0.589 *$ \\
\hline
\end{tabular}

(* Significant at $0.05 \%$, ** Significant at $0.01 \%$ )

$\mathbf{P}_{1}$ - Sowing to emergence $\quad \mathbf{P}_{2}$ - Emergence to panicle initiation (PI)

$\mathbf{P}_{4^{-}}$Flag leaf to boot stage $\quad \mathbf{P}_{5^{-}}$Boot stage to heading

$\mathbf{P}_{7}$ - Flowering to milk stage $\quad \mathbf{P}_{8}$ - Dough stage

$\mathbf{P}_{\mathbf{3}}$ - PI to flag leaf stage

$\mathbf{P}_{\mathbf{6}}-$ Heading to $50 \%$ flowering

$\mathbf{P}_{9}$ - Physiological maturity 
Table.4 Predicted and observed grain yield $\left(\mathrm{kg} \mathrm{ha}^{-1}\right)$ of sorghum by multiple regression at various phenophases stages

\begin{tabular}{|c|c|c|c|c|}
\hline Phenophase & $\begin{array}{c}\text { Predicted } \\
\text { Yield }\left(\mathrm{kg} \mathrm{ha}^{-1}\right) \\
(\mathrm{P})\end{array}$ & $\begin{array}{c}\text { Observed } \\
\text { Yield }\left(\mathrm{kg} \mathrm{ha}^{-1}\right) \\
(\mathrm{O})\end{array}$ & $\begin{array}{c}\text { Difference (kg) } \\
\text { (P-O) }\end{array}$ & Error $(\%)$ \\
\hline $\mathbf{P}_{2}$ & 1334.90 & 1335.85 & -0.95 & 0.07 \\
\hline $\mathbf{P}_{4}$ & 1319.68 & 1335.85 & -16.17 & 1.21 \\
\hline $\mathbf{P}_{6}$ & 1328.79 & 1335.85 & -7.06 & 0.52 \\
\hline $\mathbf{P}_{7}$ & 1325.05 & 1335.85 & -10.76 & 0.80 \\
\hline $\mathbf{P}_{8}$ & 1396.80 & 1335.85 & 60.95 & 4.62 \\
\hline $\mathbf{P}_{9}$ & 1363.11 & 1335.85 & 27.26 & 2.04 \\
\hline $\begin{array}{l}\text { - Emergence to } \mathrm{p} \\
\text {-Heading to } 50 \% \\
\text { Dough stage }\end{array}$ & $\begin{array}{l}\text { icle initiation } \\
\text { lowering }\end{array}$ & $\begin{array}{l}\mathbf{P}_{4^{-}} \text {Flag leaf to boot } \\
\mathbf{P}_{7^{-}} \text {Flowering to mi } \\
\mathbf{P}_{9^{-}} \text {Physiological } \mathrm{m}\end{array}$ & & \\
\hline
\end{tabular}

Table.5 The multiple regression equation fitted with weather parameter at different growth stages

\begin{tabular}{|c|c|c|c|}
\hline $\begin{array}{l}\text { Sr. } \\
\text { No. }\end{array}$ & $\begin{array}{l}\text { Phenophase stages in } \\
\text { Sorghum }\end{array}$ & Multiple regression equation & $\mathbf{R}^{2}$ \\
\hline 1 & $\begin{array}{l}\text { Emergence to panicle } \\
\text { initiation }\end{array}$ & $\begin{array}{l}Y=-29380.5-10.93 X_{1}+212.34 X_{2}+ \\
251.9643 X_{3}+309.34 X_{4}+81.15 X_{5}-8.99 X_{6} \\
+2964.00 X_{7}-640.95 X_{8}-1053.08 X_{9}\end{array}$ & 0.88 \\
\hline 2 & Flag leaf to boot stage & $\begin{array}{l}Y=-33190.0+359.92 X_{1}-5560.80 X_{2}-505.49 \\
X_{3}+32.90 X_{4}+333.05 \quad X_{5}+256.66 X_{6}+ \\
3241.52 X_{7}--1469.99 X_{8}+137.25 X_{9}\end{array}$ & 0.86 \\
\hline 3 & Heading to $50 \%$ flowering & $\begin{array}{l}Y=-11245.2-5.527 X_{1}+239.13 X_{2}+123.40 \\
X_{3}+95.72 X_{4}+75.30 X_{5}-12.36 X_{6}-705.02 X_{7}- \\
216.72 X_{8}+1104.24 X_{9}\end{array}$ & 0.79 \\
\hline 4 & Flowering to milk stage & $\begin{array}{l}Y=-7924.50-10.37 X_{1}-156.37 X_{2}+55.11 \\
X_{3}+32.24 X_{4}+61.27 X_{5}-6.44 X_{6}+189.02 \\
X_{7}+153.51 X_{8}-46.58 X_{9}\end{array}$ & 0.79 \\
\hline 5 & Dough stage & $\begin{array}{l}Y=-4503.24-36.83 X_{1}+949.45 X_{2}+-25.19 \\
X_{3}-297.97 X_{4}+89.07 X_{5}+132.05 X_{6} \\
+1544.69 X_{7}-1264.23 X_{8}-447.09 X_{9}\end{array}$ & 0.74 \\
\hline 6 & $\mathbf{P}_{9}$ - Physiological maturity & $\begin{array}{l}Y=4280.19+7.59 X_{1}+18.23 X_{2}-119.45 X_{3}- \\
125.19 X_{4}+25.87 X_{5}+10.51 X_{6}+56.29 X_{7}+ \\
113.66 X_{8}-263.93 X_{9}\end{array}$ & 0.80 \\
\hline
\end{tabular}




\section{Statistical model for yield forecasting}

The multiple regression between weather parameter and grain yield at different critical growth stages of sorghum worked out and multiple regression equation was derived at different growth stages of sorghum viz., emergence to panicle initiation (PI), flag leaf to boot stage, heading to $50 \%$ flowering, flowering to milk stage, dough stage and physiological maturity, respectively. The multiple regression equation fitted with weather parameter at different growth stages in order to forecast the sorghum grain yield (Table 5). These above multiple regression equations are resembled with $Y=\beta_{0}+\beta_{1} X_{1}+\beta_{2} X_{2}+\beta_{3} X_{3}+\ldots \ldots \beta_{i} X_{i}$

Where, $\mathrm{Y}$ is yield (Dependent parameter) and $X_{i}$ are weather parameters (independent parameters) respectively, $\beta_{0}$ and $\beta_{\mathrm{i}}$ are constants.

The multiple regression coefficients $\left(R^{2}\right)$ at each stage showed a high degree of goodness of fit as indicated by as high as 0.79 to 0.88 . The multiple regression models were found significant and similar results are given by Rana et al., (1998).

The regression model developed for different growth stages showed accurate and useful prediction because of its error percentage is very less and it is ranged in between 0.07 to 4.62 percentages.

Data given in Table 4 is indicated that error percentage in between predicted grain yield at different growth stages and actual recorded grain yield (i.e. observed yield) compared. The observed yield was compared with estimated yield; developed by multiple regression model and percentage error in estimated yield is also calculated (Table-4) at different growth stages viz., at emergence to panicle initiation $(-0.07 \%)$, flag leaf to boot stage $(-1.21 \%)$, heading to $50 \%$ flowering (-
$0.52 \%)$ and at flowering to milk stage (-0.80 $\%)$ stage. While, it was observed over estimated at dough stage $(4.62 \%)$ and at physiological maturity $(2.09 \%)$. It means that the regression model developed for different growth stages of sorghum showed accurate and useful yield prediction with low percentage error.

However, validation of this regression model is required for practical utilization to give yield prediction at different growth stages of Kharif sorghum before harvesting one month to two and half month.

Conclusion of the study is as follows:

On the basis of observed, tabulated and analyzed data (i.e. biometric and yield contributing character, it is recommended that sowing may be done in 24 MW (11 to 17 June) for grain yield, followed by sowing in $25^{\text {th }}$ MW (18 to 24 June) for highest grain and fodder yield and variety PSH-71 optimum for sowing in Kharif season at Parbhani location in Marathwada region.

The multiple regression model at flag leaf to boot stage and physiological maturity stage is $\mathrm{Y}=-33190.0+359.92 \mathrm{X}_{1}-5560.80 \mathrm{X}_{2}-$ $505.49 \mathrm{X}_{3}+32.90 \mathrm{X}_{4}+333.05 \mathrm{X}_{5}+256.66$ $\mathrm{X}_{6}+3241.52 \mathrm{X}_{7}-1469.99 \mathrm{X}_{8}+137.25 \mathrm{X}_{9}$ and $\mathrm{Y}=4280.19+7.59 \mathrm{X}_{1}+18.23 \mathrm{X}_{2}-$ $119.45 \mathrm{X}_{3}-125.19 \mathrm{X}_{4}+25.87 \mathrm{X}_{5}+10.51 \mathrm{X}_{6}$ $+56.29 \mathrm{X}_{7}+113.66 \mathrm{X}_{8}-263.93 \mathrm{X}_{9}$ is significant and it may be used to yield forecast of Kharif sorghum in advance two to two and half months and 15 days before harvesting at Parbhani location.

\section{References}

Anonymous. 2012. www.indiastat.com. Area, production and productivity of sorghum. (Ministry of Agriculture Govt. of India).

Alma D. Baez-Gomzaler and Jones, J. G. 
W.1995. Models of sorghum and perlmillet to predict the forage dry matter production in semi aeridmexico. 2 Regression models. Agricultural system 47: 147-159.

Baig, M. S., Shankiti, A. AL. 1994. Effect of sowing dates on different parental lines of sorghum hybrids. PKV Res. J. Vol. 18(2): 206-208.

Bhoite, S. V. and Nimbalkar. 1997. Performance of kharif crops under different planting time $J$. of Maharashtra Agric. University. 22(1): 345-346.

Jadhav, M. G., Maniyar, V. G. and More, G. R. 2010. Influence of changes in weather on phenology and grain yield of kharif sorghum at parbhani in Maharashtra. ISPRS Archives xxxVIII8 w3 workshop proceeding. Impact of climate change on Agriculture 401.

Rana, V. K. S., Singh Daljit, Ahluwalia, M. 1998. Multiple regression equation and selection for grain and fodder yield in sorghum Vulgare. Indian J. Genetics., 58(4): 485-493.
Sonwar, S. N., Wani, A. G., Dacharne, D. P., Patil, H. M. 2008. Effect of seeding dates and planting layouts on growth, Juice quality and grain yield of sweet sorghum. J. Maharashtra agric. Univ., 33(1): 108-110.

Suchit, K. Rai, BRD Gupta and Sunil Kumar. 2006. Simulation as tool for analyzing climatic risk to forage sorghum production in semi-arid region of India: Effect of cultivar and planting date. Indian J. of Agricultural Sciences., 76(3): 162-166.

Sunil Kausik, Singh, K. K., Jiotode, D. J. and Baxla, A. K. 2007. Exploring application of seasonal climate forecast using viable management option in sorghum at Akola, Maharashtra, India. Journal of Agro-meteorology., 9(1): 1119.

Umrani, N. K., Ramshe, D. G., Joshi, A. C. and Rao, K. V. 1988.Loss in yield of sorghum entries due to late sowing under varying NPK fertilization. $J$. Maharashtra agric. Univ., 13(2): 127128.

\section{How to cite this article:}

Burade, D. D., M. B. Jadhav and Nirwal, A. D. 2020. Correlation Studies and Yield Forecasting Regression Model of kharif sorghum [Sorghum bicolor (L.)]. Int.J.Curr.Microbiol.App.Sci. 9(11): 3120-3128. doi: https://doi.org/10.20546/ijcmas.2020.911.376 